\title{
IDENTIFIKASI FAKTOR-FAKTOR YANG MEMENGARUHI PERUBAHAN PEMANFAATAN LAHAN PERUMAHAN UNTUK TUJUAN KOMERSIAL DI KORIDOR JALAN DR. WAHIDIN SUDIROHUSODO KOTA PONTIANAK
}

\author{
Meli Ardiana ${ }^{1)}$, Ely Nurhidayati ${ }^{2)}$, Meta Indah Fitriani ${ }^{2)}$ \\ 1) Mahasiswa S1 Jurusan Perencanaan Wilayah dan Kota, Universitas Tanjungpura, \\ 2) Dosen S1 Jurusan Perencanaan Wilayah dan Kota, Universitas Tanjungpura. \\ Email : $\underline{\text { meliardiana12@gmail.com }}$
}

\begin{abstract}
The Corridor Street dr. Wahidin Sudirohusodo with an area of $0.425 \mathrm{~km} 2$ or $3 \%$ of the total area of Pontianak City District, Sungai Jawi Village. Street Dr. Corridor Wahidin Sudirohusodo in the RTRW of Pontianak City in 2013-2033 which is 95\% of the allocation for residential areas. The purpose of this study was to determine the factors that influence changes in the use of residential land for commercial purposes in the corridor of Street dr. Wahidin Sudirohusodo. This study uses a quantitative approach with quantitative descriptive analysis techniques and descriptive statistical analysis techniques using cross tabulation and chi square. The results showed that the corridor of Street dr. Wahidin Sudirohusodo can conclude that from 2015 to 2021 the development of trade and services increased by $4.89 \mathrm{Ha}$ or $28.5 \%$ of the total study area and settlements decreased by $3.07 \mathrm{Ha}$ or $17.9 \%$ of the total study area. The results of crosstab and chi square analysis, the factors that influence changes in residential land use for commercial purposes, namely aspects of land ownership for education level, occupation, length of stay, and land ownership status have a relationship, for aspects of accessibility and completeness of public utilities the variable is fixed value. because the community feels satisfied and this is a very supportive factor for the community to open a business, and for the fiscal aspect of land there is a relationship.
\end{abstract}

Keywords : Trade and services, land use change.

\begin{abstract}
ABSTRAK
Koridor Jalan dr. Wahidin Sudirohusodo dengan luas $0,425 \mathrm{~km}^{2}$ atau 3\% dari total wilayah Kecamatan Pontianak Kota, Kelurahan Sungai Jawi. Koridor Jalan Dr. Wahidin Sudirohusodo di dalam RTRW Kota Pontianak Tahun 2013-2033 yaitu 95\% merupakan peruntukkan kawasan perumahan. Tujuan penelitian ini untuk mengetahui faktor-faktor yang memengaruhi perubahan pemanfaatan lahan perumahan untuk tujuan komersial di koridor Jalan dr. Wahidin Sudirohusodo. Penelitian ini menggunakan pendekatan kuantitatif dengan teknik analisis deskriptif kuantitatif dan teknik analisis statistik deskriptif menggunakan tabulasi silang dan chi square. Hasil penelitian menunjukkan koridor Jalan dr. Wahidin Sudirohusodo dapat disimpulkan bahwa dari tahun 2015 sampai ke tahun 2021 perkembangan perdagangan dan jasa naik sebesar 4,89 Ha atau $28,5 \%$ dari total wilayah kajian dan permukiman menyusut sebesar 3,07 Ha atau 17,9\% dari total wilayah kajian. Hasil analisa crosstab dan chi square, faktor-faktor yang memengaruhi perubahan pemanfaatan lahan perumahan untuk tujuan komersial yaitu aspek kepemilikan lahan untuk tingkat pendidikan, pekerjaan, lama tinggal, dan status kepemilikan lahan memiliki keterkaitan hubungan, untuk aspek aksesibilitas dan kelengkapan utilitas umum variabel bernilai tetap dikarenakan masyarakat merasa sudah puas dan ini menjadi faktor yang sangat mendudukung masyarakat membuka usaha, dan untuk aspek fiskal lahan memiliki keterkaitan hubungan.
\end{abstract}

Kata kunci : Perdagangan dan jasa, perubahan pemanfaatan lahan. 


\section{PENDAHULUAN}

Kecamatan Pontianak Kota, Kota Pontianak memiliki luas sebesar 15,51 km2, dengan total wilayah kajian dengan luas $0,425 \mathrm{~km} 2$ atau $3 \%$ dari total wilayah Kecamatan Pontianak Kota. Lokasi kajian ini berada di koridor Jalan Dr. Wahidin Sudirohusodo, Kelurahan Sungai Jawi yang termasuk ke dalam jaringan jalan kolektor sekunder. PERDA Nomor 2 Tahun 2013 Tentang RTRW Kota Pontianak Tahun 2013-2033, Kelurahan Sungai Jawi di peruntukkan sebagai kawasan perumahan termasuk koridor Jalan Dr. Wahidin Sudirohusodo sebesar 95\%. Rencana pola ruang pada kawasan peruntukan perumahan di Kelurahan Sungai Jawi yaitu sebagai kawasan peruntukan perumahan skala besar dan kawasan perumahan skala menengah, tetapi hingga saat ini sudah banyak terjadi perubahan terhadap penggunaan lahannya menjadi tujuan komersial. Perubahan di Koridor Jalan Dr. Wahidin Sudirohusodo ini dapat dilihat pada tahun 2015 luas wilayah untuk perdagangan dan jasa sebesar 9,06 Ha atau 52,9\% dan pada tahun 2021 luas wilayah untuk perdagangan dan jasa sebesar $13,95 \mathrm{Ha}$ atau $81,4 \%$, total perubahan yang terjadi terhadap perdagangan dan jasa naik sebesar 4,89 Ha atau $28,5 \%$.

\section{METODOLOGI PENELITIAN}

Penelitian dengan pendekatan penelitian kuantitatif, pendekatan kuantitatif dilakukan dengan teknik pengumpulan data kuesioner. Kuesioner ini adalah teknik pengumpulan data primer pada pendekatan kuantitatif yang menjadi bahan untuk melakukan analisis data, baik data statistik deskriptif juga data statistik inferensial. Output analisis tersebut, peneliti berusaha menaruh makna yang mendalam terhadap data statistik yang diperoleh (Mulyadi, 2011).

Penelitian kuantitatif ini yaitu uji hipotesis bertujuan mengetahui apakah ada berpengaruh/hubungan variabel yang mempengaruhi terhadap variabel yang dipengaruhi dengan teknik analisis deskriptif kuantitatif dan teknik analisis statistik deskriptif dengan menggunakan tabulasi silang dan chi square.

\section{a. Populasi}

Populasi yaitu pemilik lahan yang ada di Koridor Jalan Dr. Wahidin Sudirohusodo untuk lahan perumahan maupun yang non perumahan (komersial). Adapun populasi nya sebanyak 229 orang yang di hitung berdasarkan jumlah bangunan di sepanjang Koridor Jalan Dr. Wahidin Sudirohusodo. 


\section{b. Sampel}

Sampel yaitu sebagian dari populasi, sifat populasi dapat ditentukan oleh waktu dan sumber daya peneliti (Furchan, 2004). Penelitian ini akan menentukan jumlah sampel yang di teliti yaitu dihitung menggunakan rumus Slovin untuk mengetahui jumlah sampel di Koridor Jalan Dr. Wahidin Sudirohusodo.

$$
\text { Rumus Slovin }=\mathrm{n}=\frac{N}{1+N e^{2}}
$$

Ket:

$\mathrm{n}=$ total sampel

$\mathrm{N}=$ total populasi

$\mathrm{e}=$ Margin of error (Margin of error yang ditetapkan $=10 \%$ atau 0,1 ).

Hasil dari perhitungan tersebut maka jumlah keseluruhan sampelnya sebanyak 70 orang pemilik lahan, adapun pada lampiran kuesioner diperuntukkan untuk 55 orang yang sudah melakukan perubahan pemanfaatan fungsi lahan perumahan untuk tujuan komersial dan 15 orang yang tidak melakukan perubahan terhadap pemanfaatan lahannya. Penarikan sampel dengan teknik purposive sampling dengan sampel yang dipilih berdasarkan pertimbangan tertentu, adapun purposive sampling ini berdasarkan ciri tertentu adalah responden yang memiliki lahan yang melakukan perubahan pada fungsi lahannya dan tidak melakukan perubahan terhadap fungsi lahannya.

\section{c. Variabel Penelitian}

Variabel terikat (Dependen Variable) yaitu pemanfaatan lahan perumahan, sedangkan variable bebas (Independen Variable) yaitu aspek kelengkapan utilitas umum, aspek aksesibilitas lahan, aspek kepemilikan lahan, dan aspek fiskal lahan.

\section{d. Chi Square}

Pengambilan hasil pada uji chi square bisa melihat nilai tabel output "Chi Square Test" berdasarkan output pengolahan data Statistical Package for the Social Sciences. Pengambilan hasil uji chi square, bisa berdasarkan 2 hal, yakni membandingkan antara nilai Asymp. Sig. menggunakan batas kritis yakni 0,05 dan bisa juga menggunakan cara membandingkan antara nilai chi square hitung menggunakan nilai chi square tabel dalam sig 5\% (Santoso, 2014). 


\section{e. Crosstab}

Metode crosstab adalah penyajian data berbentuk tabulasi, yang mencakup baris dan kolom (Manullang, dkk, 2014). Metode ini dipakai lantaran mempunyai proses analisis dan kebutuhan data yang sederhana, namun mempunyai output yang bisa dipertanggungjawabkan secara statistik (Manullang, dkk, 2014).

\section{HASIL DAN PEMBAHASAN}

\section{a. Gambaran Umum Wilayah Studi}

Lokasi kajian termasuk dalam salah satu kelurahan dari Kecamatan Pontianak Kota. Kelurahan Sei Jawi dibentuk dengan PERDA Kota Pontianak Nomor 5 Tahun 2002 tentang Pembentukan Kecamatan Pontianak Kota dan Kelurahan Sei Jawi yang merupakan hasil pemekaran wilayah Kelurahan Sei Jawi Dalam, Sungai Bangkong dan Kelurahan Pal Lima. Kelurahan Sei Jawi memiliki luas sebesar 702 Ha dengan total wilayah kajian yang memiliki luas sebesar 42,5 Ha atau 6\% dari total wilayah Kelurahan Sungai Jawi. Peta wilayah kajian dilihat pada gambar 1. Secara administratif Kelurahan Sei Jawi berbatasan dengan:

Utara : Berbatasan dengan Kelurahan Sei Jawi Dalam dan Kelurahan Pal Lima

Selatan : Berbatasan dengan Kelurahan Sei Bangkong

Timur : Berbatasan dengan Kelurahan Mariana

Barat : Berbatasan dengan Desa Pal IX 


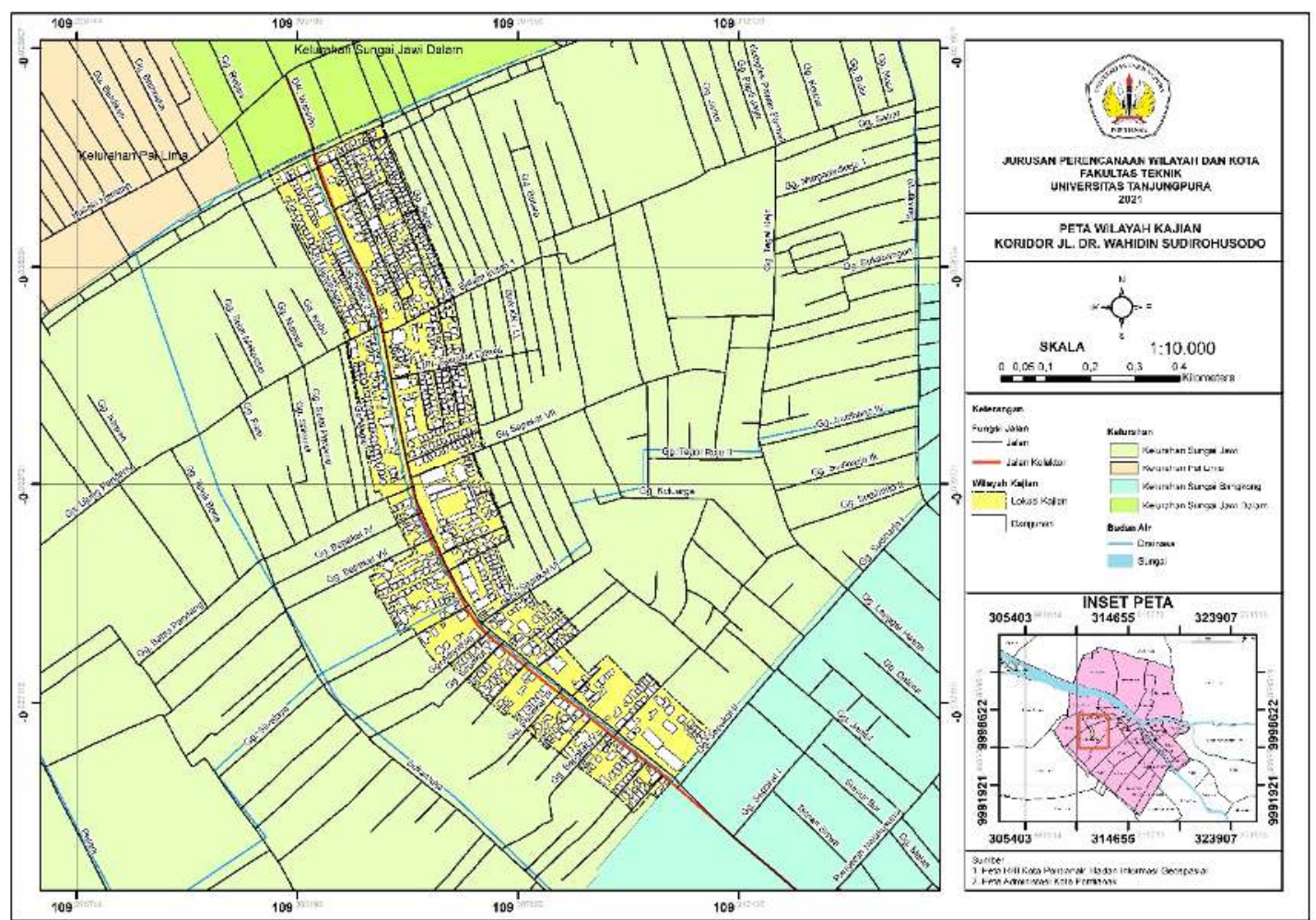

Gambar 1. Peta Wilayah Studi

\section{b. Karakteristik Wilayah Studi}

Karakteristik masyarakat di sepanjang koridor Jalan Dr. Wahidin Sudirohusodo, Kelurahan Sungai Jawi dapat di kelompokkan berdasarkan pendidikan, pekerjaan, penghasilan, jumlah anggota keluarga, lama tinggal, dan status kepemilikan lahan yang dapat di ketahui berdasarkan hasil kuesioner yang di dapat berikut:

\section{1) Pendidikan}

Pendidikan masyarakat yang di dapat dari kuesioner sebanyak 70 responden, maka dapat dilihat bahwa tingkat pendidikan di wilayah tersebut yang paling terbanyak yaitu tamat SMA dengan total $64,3 \%$ atau sama dengan 45 responden dan yang paling rendah yaitu tamat SD dengan total $1,4 \%$ atau sama dengan 1 responden, tingkat pendidikan dilihat pada tabel 1 .

Tabel 1. Pendidikan

\begin{tabular}{|l|l|c|c|}
\hline No. & Pendidikan & $\begin{array}{c}\text { Jumlah } \\
(\text { orang) }\end{array}$ & $\begin{array}{c}\text { Persentase } \\
(\%)\end{array}$ \\
\hline 1. & SD & 1 & 1,4 \\
\hline 2. & SMP & 7 & 10 \\
\hline 3. & SMA & 46 & 64,4 \\
\hline 4. & D3 & 5 & 7,1 \\
\hline 5. & S1 & 10 & 14,3 \\
\hline
\end{tabular}




\begin{tabular}{|l|l|c|c|}
\hline No. & Pendidikan & $\begin{array}{c}\text { Jumlah } \\
\text { (orang) }\end{array}$ & $\begin{array}{c}\text { Persentase } \\
(\%)\end{array}$ \\
\hline 6. & S2 & 1 & 1,4 \\
\hline 7. & S3 & 1 & 1,4 \\
\hline \multicolumn{2}{|c|}{ Total } & 70 & 100 \\
\hline
\end{tabular}

Sumber: Hasil Kuesioner, 2021

2) Pekerjaan

Mata Pencaharian/pekerjaan masyarakat di wilayah studi yang di dapat dari kuesioner sebanyak 70 responden, maka dapat dilihat bahwa mata pencaharian di wilayah tersebut yang paling banyak yaitu sebagai pengusaha/wiraswasta dengan total $62,9 \%$ atau sama dengan 44 responden dan yang paling sedikit yaitu sebagai pensiunan dan guru yayasan dengan total 1,4\% atau sama dengan 1 responden, mata pencaharian dilihat pada tabel 2.

Tabel 2. Pekerjaan

\begin{tabular}{|l|l|c|c|}
\hline No. & \multicolumn{1}{|c|}{ Pekerjaan } & Jumlah (orang) & Persentase (\%) \\
\hline 1. & Karyawan & 22 & 31,4 \\
\hline 2. & Pengusaha/wiraswasta & 44 & 62,9 \\
\hline 3. & PNS & 2 & 2,9 \\
\hline 3. & Guru yayasan & 1 & 1,4 \\
\hline 4. & Pensiunan & 1 & 1,4 \\
\hline \multicolumn{2}{|c|}{ Total } & 70 & 100 \\
\hline
\end{tabular}

Sumber: Hasil Kuesioner, 2021

3) Penghasilan

Penghasilan masyarakat di wilayah studi yang di dapat dari kuesioner sebanyak 70 responden, maka dapat dilihat bahwa penghasilan di wilayah tersebut yang paling dominan yaitu Rp.1.000.000,- s/d Rp. 3.000.000 dengan total 48,6\% setara dengan 34 responden, kemudian yang berpenghasilan > Rp. 3.000.000,- dengan total $44,3 \%$ atau sama dengan 31 responden, serta berpenghasilan Rp. 500.000,s/d Rp. 1.000.000,- total 7,1\% atau sama dengan 5 responden, penghasilan dilihat pada tabel 3 .

Tabel 3. Penghasilan

\begin{tabular}{|l|l|c|c|}
\hline No. & \multicolumn{1}{|c|}{ Penghasilan } & $\begin{array}{c}\text { Jumlah } \\
(\text { orang) }\end{array}$ & $\begin{array}{c}\text { Persentase } \\
(\%)\end{array}$ \\
\hline 1. & $<$ Rp. 500.000,- & 0 & 0 \\
\hline 2. & Rp. 500.000,- s/d Rp. 1.000.000,- & 5 & 7,1 \\
\hline 3. & Rp. 1.000.000,-s/d Rp. 3.000.000,- & 34 & 48,6 \\
\hline 4. & > Rp. 3.000.000,- & 31 & 44,3 \\
\hline \multicolumn{2}{|c|}{ Total } & 70 & 100 \\
\hline
\end{tabular}

Sumber: Hasil Kuesioner, 2021 
4) Jumlah Anggota Keluarga

Wilayah studi yang di dapat dari kuesioner sebanyak 70 responden dengan persentase tertinggi yaitu anggota keluarga yang beranggotakan sebanyak 4 orang dengan 47,1\% atau sama dengan 33 responden, kemudian dengan persentase terendah yaitu anggota keluarga yang beranggotakan sebanyak 8 orang dengan 1,4\% atau sama dengan 1 responden, dilihat pada tabel 4 .

Tabel 4. Jumlah Anggota Keluarga

\begin{tabular}{|l|l|c|c|}
\hline No. & $\begin{array}{c}\text { Anggota } \\
\text { Keluarga }\end{array}$ & $\begin{array}{c}\text { Jumlah } \\
\text { (orang) }\end{array}$ & $\begin{array}{c}\text { Persentase } \\
(\%)\end{array}$ \\
\hline 1. & 1 orang & 2 & 2,9 \\
\hline 2. & 2 orang & 5 & 7,1 \\
\hline 3. & 3 orang & 11 & 15,8 \\
\hline 4. & 4 orang & 33 & 47,1 \\
\hline 5. & 5 orang & 15 & 21,4 \\
\hline 6. & 6 orang & 3 & 4,3 \\
\hline 7. & 8 orang & 1 & 1,4 \\
\hline \multicolumn{4}{|c|}{ Total } \\
\hline
\end{tabular}

Sumber: Hasil Kuesioner, 2021

5) Lama Tinggal

Lama tinggal masyarakat di wilayah studi yang di dapat dari kuesioner sebanyak 70 responden yang sudah tinggal selama 4 sampai dengan 10 tahun ada sebanyak $34,2 \%$ atau sama dengan 24 responden, kemudian yang sudah tinggal selama lebih dari 10 tahun ada sebanyak 32,9\% atau sama dengan 23 responden, yang tinggal selama 1 sampai dengan 4 tahun ada sebanyak 22,9\% atau sama dengan 16 responden dan yang sudah tinggal selama 0 sampai dengan 1 tahun ada sebanyak 10\% atau sama dengan 7 responden, lama tinggal dapat dilihat pada tabel 5 .

Tabel 5. Lama Tinggal

\begin{tabular}{|c|c|c|c|}
\hline No. & $\begin{array}{l}\text { Lama Tinggal } \\
\text { (Tahun) }\end{array}$ & $\begin{array}{l}\text { Jumlah } \\
\text { (orang) }\end{array}$ & $\begin{array}{c}\text { Persentase } \\
(\%)\end{array}$ \\
\hline 1. & $0 \mathrm{~s} / \mathrm{d} 1$ & 7 & 10 \\
\hline 2. & $1 \mathrm{~s} / \mathrm{d} 4$ & 16 & 22,9 \\
\hline 3. & $4 \mathrm{~s} / \mathrm{d} 10$ & 24 & 34,2 \\
\hline 4. & $>10$ & 23 & 32,9 \\
\hline \multicolumn{2}{|c|}{ Total } & 70 & 100 \\
\hline
\end{tabular}

Sumber: Hasil Kuesioner, 2021

6) Status Kepemilikan Lahan

Status kepemilikan lahan masyarakat di wilayah studi yang di dapat dari kuesioner sebanyak 70 responden, yaitu sebanyak 52,9\% atau sama dengan 37 responden 
merupakan hak milik sendiri, sedangkan sebanyak 47,1\% atau sama dengan 33 responden yaitu bukan hak milik atau menyewa, status kepemilikan lahan yang dilihat pada tabel 6 .

Tabel 6. Status Kepemilikan Lahan

\begin{tabular}{|l|l|c|c|}
\hline No. & $\begin{array}{c}\text { Status Kepemilikan } \\
\text { Lahan }\end{array}$ & $\begin{array}{c}\text { Jumlah } \\
\text { (orang) }\end{array}$ & $\begin{array}{c}\text { Persentase } \\
(\%)\end{array}$ \\
\hline 1. & Hak Milik & 37 & 52,9 \\
\hline 2. & Bukan Hak Milik & 33 & 47,1 \\
\hline \multicolumn{2}{|c|}{ Total } & 70 & 100 \\
\hline
\end{tabular}

Sumber: Hasil Kuesioner, 2021

\section{c. Perubahan Fungsi Pemanfaatan Lahan Perumahan}

Pemanfaatan perumahan di koridor Jalan Dr. Wahidin Sudirohusodo berkembang pesat dan diikuti perubahan pemanfaatan perumahan menjadi perdagangan dan jasa, tertuang di dalam RTRW Kota Pontianak Tahun 2013-2033, pada bagian rencana sistem pusat pelayanan kota yaitu sebagai sub PPK III yang memiliki fungsi perdagangan dan jasa, pendidikan menengah dan tinggi, pelayanan kesehatan, perumahan kepadatan sedang dan perkantoran, adapun peta fungsi bangunan tahun 2021 dilihat pada gambar 2 dan peta penggunaan lahan tahun 2021 dilihat pada gambar 3.

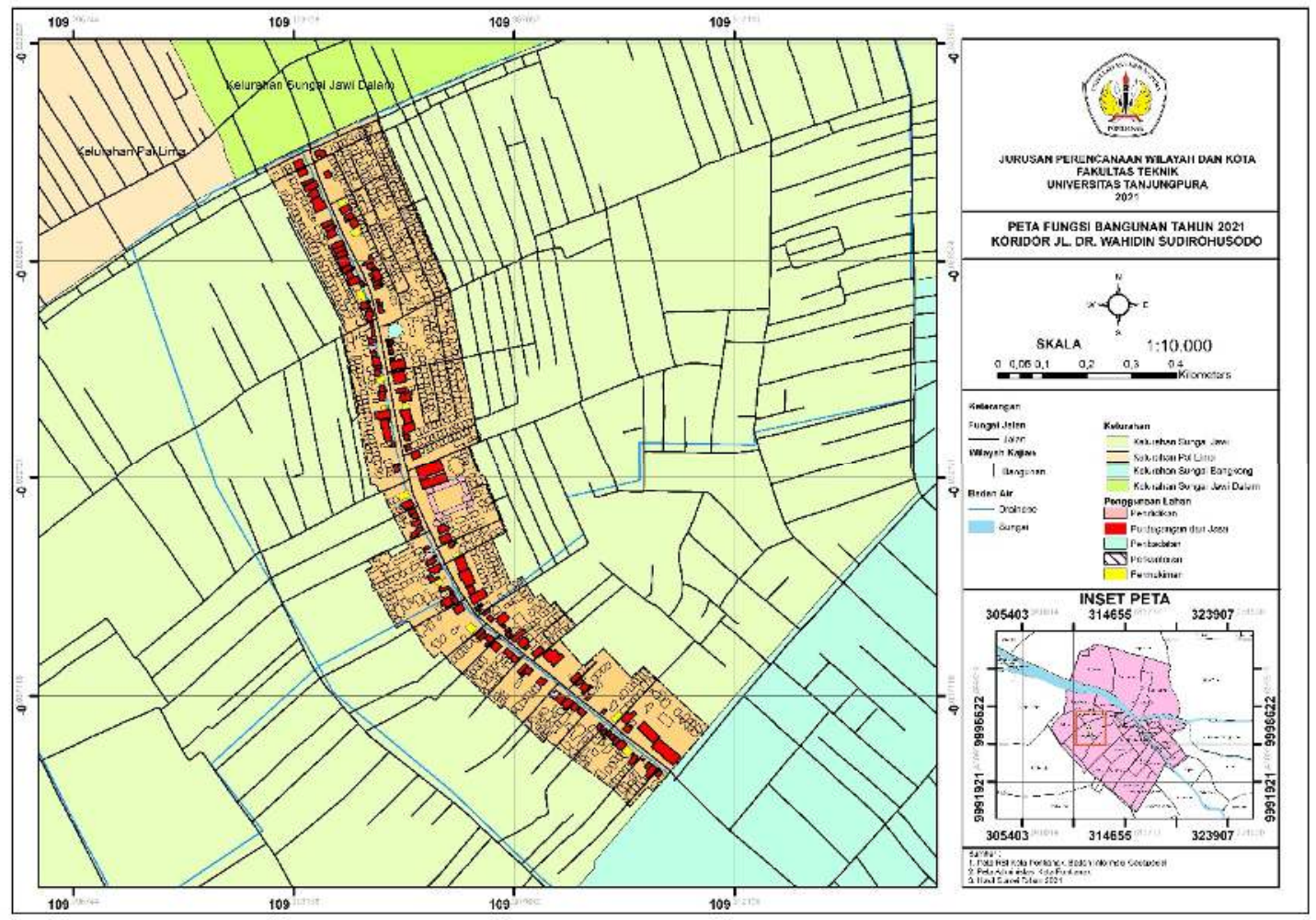

Gambar 2. Peta Fungsi Bangunan 


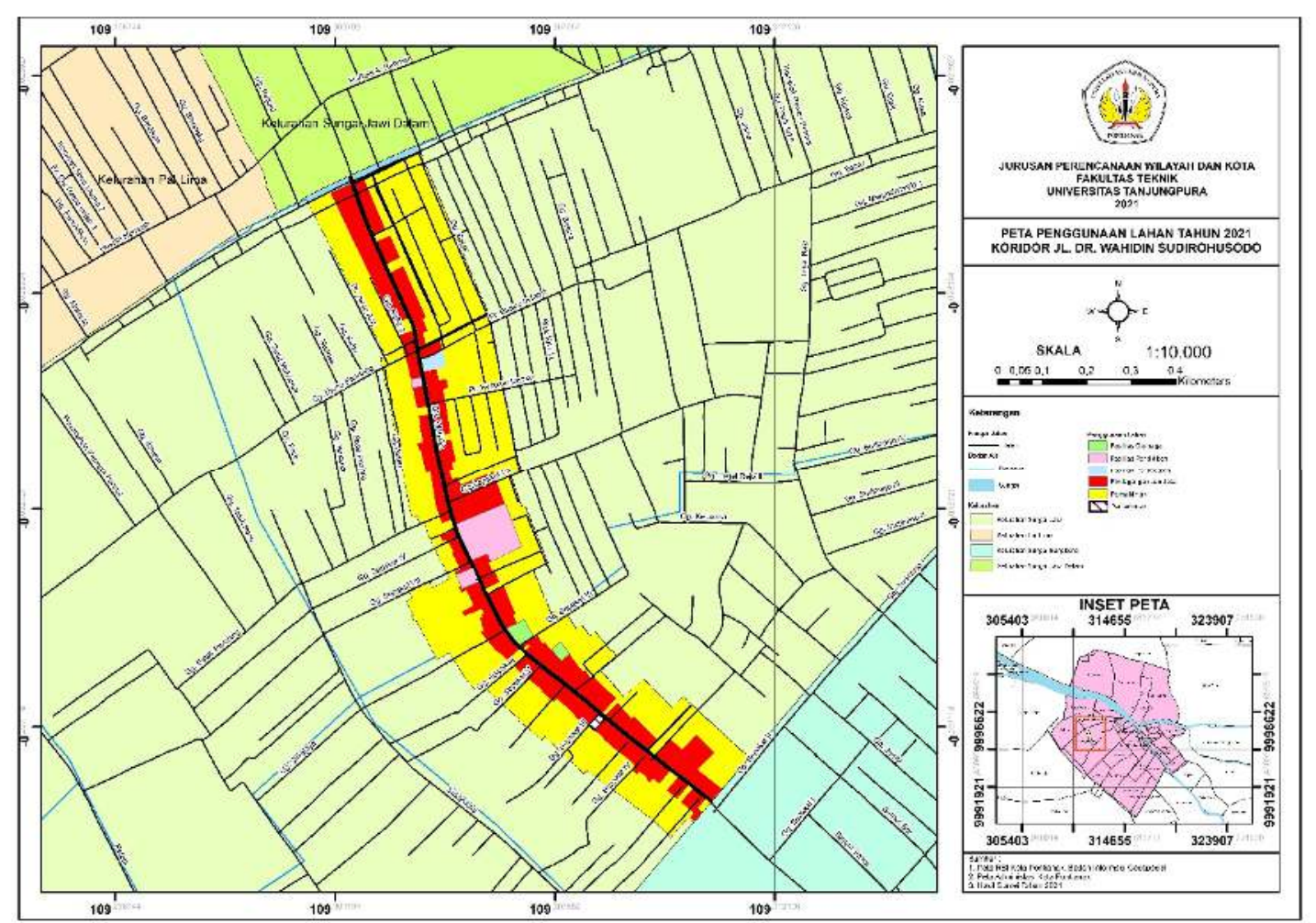

Gambar 3. Peta Penggunaan Lahan Tahun 2021

\section{d. Faktor-Faktor Perubahan Pemanfaatan Lahan Perumahan menjadi Tujuan Komersial}

Aspek kepemilikan lahan dilihat dari karakteristik pemilik lahan yaitu berdasarkan tingkat pendidikan, mata pencaharian, jumlah anggota keluarga, penghasilan, lama tinggal, dan status kepemilikan lahan dengan analisa crosstab dan analisa Chi-Square, sehingga dapat dilihat identifikasinya terkait ada atau tidak hubungan antar variabel. Aspek kepemilikan lahan yang terdiri dari tingkat pendidikan, pekerjaan, lama tinggal, dan status kepemilikan lahan, berdasarkan analisa yang telah dilakukan menggunakan analisa crosstab dan chi square, untuk pendidikan nilai chi square hitung 21,555 > chi square tabel 12,591 dan untuk pekerjaan nilai chi square hitung 16,815 > chi square tabel 9,487, disimpulkan memiliki keterkaitan hubungan terhadap perubahan pemanfaatan lahan, karena pendidikan berpengaruh karena bisa disebabkan karena sulitnya mencari pekerjaan yang tetap sehingga lebih memilih membuka usaha sendiri dan memanfaatkan lahan yang ada. Untuk lama tinggal nilai chi square hitung $10,735>$ chi square tabel 7,814 dan untuk status kepemilikan lahan nilai chi square hitung $17,027>$ chi square tabel 3,841, sehingga disimpulkan memiliki keterkaitan hubungan terhadap perubahan pemanfaatan lahan, karena status kepemilikan lahan dapat memengaruhi hak pemilik untuk merubah atau tidak lahannya untuk menambah 
penghasilan, serta lama tinggal agar dapat memahami akan apa yang diperlukan masyarakat sekitar sehingga berpengaruh dengan usaha apa yang akan dilakukannya. Untuk penghasilan nilai chi square hitung 1,477 < chi square tabel 5,991 dan untuk jumlah anggota keluarga nilai chi square hitung $4,343<$ chi square tabel 12,591, disimpulkan bahwa penghasilan dan jumlah anggota keluarga tidak memiliki keterkaitan hubungan atau pengaruh terhadap perubahan pemanfaatan lahan, karena hasil yang sudah dilakukan analisa tabulasi silang memiliki jawaban yang merata atau sama.

Aspek aksesibilitas dan aspek kelengkapan utilitas umum, berdasarkan analisa yang telah dilakukan analisa tabulasi silang dan chi square bahwa variabel tidak dapat dihitung karena variabel bernilai tetap atau jawaban responden sama tidak terdapat variasi, responden di wilayah studi sebanyak 70 orang menjawab bahwa aksesibilitas di wilayah studi lancar, dengan perubahan pemanfaatan lahan, responden merasa aksesibilitas di kawasan tersebut lancar saja serta dekat dengan pusat kota. Kelengkapan utilitas umum juga menunjukkan bahwa variabel tidak dapat dihitung karena variabel bernilai tetap atau jawaban responden sama tidak terdapat variasi, responden di wilayah studi sebanyak 70 orang menjawab bahwa kelengkapan utilitas umum di wilayah studi sudah memenuhi dan ini dilihat berdasarkan jawaban responden yang sudah dilakukan analisa tabulasi silang memiliki jawaban yang merata atau sama. Dengan aksesibilitas yang lancar serta kelengkapan utilitas di wilayah studi yang masyarakat rasakan sudah lengkap, ini juga sebagai alasan masyarakat menjadikan lahannya sebagai tempat mencari nafkah atau menambah penghasilan mereka. Aspek fiskal lahan yang dilihat dari pembayaran Pajak Bumi dan Bangunan (PBB) berdasarkan analisa yang telah dilakukan menggunakan analisa tabulasi silang dan chi square, memiliki nilai chi square hitung 27,769 > chi square tabel 9,487, sehingga dapat disimpulkan memiliki keterkaitan hubungan terhadap perubahan pemanfaatan lahan, karena besar nominal pembayaran PBB membuat masyarakat memanfaatkan lahannya untuk melakukan usaha serta dapat menambah penghasilannya, karena bagi yang memiliki status lahan hak milik tidak pelu membayar uang sewa untuk usahanya. Berikut dapat dilihat hasil analisa pada tabel 7.

Tabel 7. Hasil Analisa

\begin{tabular}{|l|l|l|}
\hline $\begin{array}{l}\text { Faktor-Faktor Perubahan Pemanfaatan Lahan } \\
\text { Perumahan Menjadi Tujuan Komersial }\end{array}$ & Terdapat/Tidaknya Hubungan \\
\hline \multirow{3}{*}{} & Tingkat Pendidikan & Terdapat hubungan/pengaruh \\
\cline { 2 - 3 } & Pekerjaan & Terdapat hubungan/pengaruh \\
\cline { 2 - 3 } & Penghasilan & Tidak terdapat hubungan/pengaruh \\
\hline
\end{tabular}




\begin{tabular}{|l|l|l|}
\hline $\begin{array}{l}\text { Faktor-Faktor Perubahan Pemanfaatan Lahan } \\
\text { Perumahan Menjadi Tujuan Komersial }\end{array}$ & Terdapat/Tidaknya Hubungan \\
\hline \multirow{4}{*}{ Aspek Kepemilkan Lahan } & $\begin{array}{l}\text { Jumlah Anggota } \\
\text { Keluarga }\end{array}$ & Tidak terdapat hubungan/pengaruh \\
\cline { 2 - 3 } & Lama Tinggal & Terdapat hubungan/pengaruh \\
\cline { 2 - 3 } & $\begin{array}{l}\text { Status Kepemilikan } \\
\text { Lahan }\end{array}$ & Terdapat hubungan/pengaruh \\
\hline \multicolumn{2}{|l|}{ Aspek Aksesibilitas } & Variabel bernilai tetap \\
\hline Aspek Kelengkapan Utilitas Umum & Variabel bernilai tetap \\
\hline Aspek Fiskal Lahan & Terdapat hubungan/pengaruh \\
\hline
\end{tabular}

Sumber: Hasil Analisa, 2021

\section{KESIMPULAN}

Berdasarkan penelitian yang dilakukan, faktor-faktor yang memengaruhi perubahan pemanfaatan lahan perumahan untuk tujuan komersial di koridor Jalan Dr. Wahidin Sudirohusodo Kota Pontianak maka diperoleh kesimpulan, pada koridor Jalan Dr. Wahidin Sudirohusodo mengalami perubahan dari perumahan menjadi perdagangan dan jasa komersial yang sangat pesat dikarenakan lokasi ini sangat strategis karena mudah dijangkau serta dekat dari pusat kota. Perubahan di Koridor Jalan Dr. Wahidin Sudirohusodo yang sangat pesat ini dapat dilihat pada tahun 2015 luas wilayah untuk perdagangan dan jasa sebesar 9,06 Ha atau 52,9\% dari total wilayah kajian dan luas wilayah untuk permukiman sebesar 3,80 Ha atau 22,2\% dari total wilayah kajian. Pada tahun 2021 luas wilayah untuk perdagangan dan jasa sebesar $13,95 \mathrm{Ha}$ atau $81,4 \%$ dari total wilayah kajian dan untuk luas wilayah permukiman sebesar $0,73 \mathrm{Ha}$ atau $4,3 \%$ dari total wilayah kajian. Dapat disimpulkan bahwa dari tahun 2015 sampai ke tahun 2021 perkembangan perdagangan dan jasa naik sebesar 4,89 Ha atau 28,5\% dari total wilayah kajian dan permukiman menyusut sebesar $3,07 \mathrm{Ha}$ atau $17,9 \%$ dari total wilayah kajian.

Hasil dari analisa crosstab dan chi square menggunakan SPSS, faktor-faktor yang memengaruhi perubahan pemanfaatan lahan yaitu aspek kepemilikan lahan, untuk tingkat pendidikan, pekerjaan, lama tinggal, dan status kepemilikan memiliki keterkaitan hubungan, untuk penghasilan dan jumlah anggota keluarga tidak memiliki keterkaitan hubungan. Aspek aksesibilitas dan Aspek kelengkapan utilitas umum ini tidak dapat dihitung karena variabel bernilai tetap atau jawaban responden sama tidak terdapat variasi. Aspek fiskal lahan yang dilihat dari tagihan PBB ini memiliki keterkaitan hubungan terhadap perubahan pemanfaatan lahan. 


\section{REFERENSI}

Furchan, A., (2004), Pengantar dalam Pendidikan, Yogyakarta: Pustaka Pelajar.

Manullang, O. R., Syabri, I., Tamin, O. Z., dan Sjafruddin, A. (2014). Karakteristik Perilaku Perjalanan Rumah Tangga Pengguna Sepeda Motor di Pinggiran Kota Semarang. Jurnal Antropologi Indonesia, 73-82.

Mulyadi, M. (2011). Penelitian Kuantitatif dan Kualitatif Serta Pemikiran Dasar Menggabungkannya. Jurnal Studi Komunikasi dan Media, 127-138.

Peraturan Daerah Kota Pontianak. (2013). Peraturan Daerah (PERDA) tentang Rencana Tata Ruang Wilayah Kota Pontianak Tahun 2013-2033. Pontianak.

Santoso, singgih. (2014). Statistik Parametrik Edisi Revisi. Jakarta : Elex Media Komputindo. 